\title{
In Vitro Effect of Methanolic Extract of Quercus infectoria Galls on Promastigotes and Amastigotes of Leishmania major (MRHO/IR/75/ER)
}

\author{
Asghar Farghi Yamchi (MSc) \\ Department of Parasitology, Faculty of \\ Medical Sciences, Zabol University of \\ Medical Sciences, Zabol, Iran \\ Mansour Dabirzadeh (PhD) \\ Department of Parasitology \& \\ Mycology, Zabol University of \\ Medical Sciences, Zabol, Iran \\ Yahya Maroufi (PhD) \\ Department of Parasitology, School of \\ Medicine, Kurdistan University of \\ Medical Sciences, Sanandaj, Iran \\ Corresponding author: Mansour \\ Dabirzadeh \\ Tel: +989131002177 \\ Email: dabirzadeh@zbmu.ic.ir \\ Address: Department of Parasitology, \\ Faculty of Medical Sciences, Zabol \\ University of Medical Sciences, Zabol, \\ Iran
}

Received : 16 Apr 2018

Revised: 19 Jun 2018

Accepted: 23 Jun 2018

\begin{abstract}
Background and objectives: Leishmania major is a flagellated parasitic protozoan that causes cutaneous leishmaniasis. Pentavalent antimony compounds are considered the first-line drugs in the treatment of cutaneous leishmaniasis. However, the use of these drugs is associated with numerous limitations and side effects. Therefore, there is a need for herbal and natural alternatives for these compounds with fewer side effects. In this study, we evaluated the in vitro activity of methanol extract of Quercus infectoria (oak galls) against promastigotes and amastigotes of $L$. major.
\end{abstract}

Methods: In this experimental study, the effect of $10,100,500$ and $1000 \mu \mathrm{g} / \mathrm{ml}$ of methanolic extract of 0 ak galls and 100, 500, 1000 and $10000 \mu \mathrm{g} / \mathrm{ml}$ of Glucantime was evaluated against $L$. major promastigotes using direct cell counting and MTT assay. Moreover, the effect of different concentrations of the extract and Glucantime was investigated on the mean number of amastigotes in macrophages after 24 and 48 hours. Data were analyzed using SPSS 16 and one- way analysis of variance.

Results: The half-maximal inhibitory concentration of the oak gall extract and Glucantime was $75 \mu \mathrm{g} / \mathrm{ml}$ and $221 \mu \mathrm{g} / \mathrm{ml}$ after 24 hours, respectively. After 24 hours, the mean number of amastigotes per macrophage was lowest at concentrations of $1000 \mu \mathrm{g} / \mathrm{ml}$ of the extract (0.9) and $10000 \mu \mathrm{g} / \mathrm{ml}$ of Glucantime (0.85).

Conclusion: Considering the inhibition of intracellular and extracellular growth of L. major, the oak gall extract might be used as an efficient and safe agent for treatment of cutaneous leishmaniasis.

KEYWORDS: Leishmaniasis, Cutaneous, Quercus.

This paper should be cited as: Farghi Yamchi A, Dabirzadeh M, Maroufi Y [In Vitro Effect of Methanolic Extract of Quercus infectoria Galls on Promastigotes and Amastigotes of Leishmania major (MRHO/IR/75/ER) ]. mljgoums. 2018; 12(5):23-28 


\section{INTRODUCTION}

Leishmaniasis is a complex disease caused by various species of the protozoan Leishmania, an intracellular parasite of humans and animals. It is prevalent in 88 countries and a common problem in tropical and subtropical regions with 1.5 million new cases reported every year. Cutaneous leishmaniasis is divided into urban dry and rural wet forms based on clinical manifestations. The parasite is transmitted by the bite of infected sand flies from the Phelbotomus genus $(1,2)$.

Pentavalent antimony compounds are considered the first-line drugs in the treatment of cutaneous leishmaniasis. However, the use of these drugs is associated with several disadvantages, including unavailability, high cost, painful injection, long-term treatment, severe toxic effects on the heart and kidneys, recurrence of the disease, scarring and drug resistance (3-5). Therefore, there is a need for herbal and natural alternatives for these compounds with fewer side effects.

Quercus infectoria (oak) is a tree of average height native to the Zagros Mountains in Iran. Scabies is a mass caused by the abnormal growth of plant tissues in response to the larval secretions of gall wasps, including Andricus sternlichti. In fact, bees lay eggs on lateral buds and at the end of the tree branches, but gall wasps appear proximal to the eggs. Scabies contains various tannins that have been used in traditional medicine and different industries including textiles and paint manufacture (6). Oak galls have astringent, antiseptic, antioxidant and blood coagulating properties, and its decoction has wound and burn healing effects (7). The alcoholic extract of oak galls exerts anti-inflammatory effects by inhibiting the formation of inflammatory intermediates $(8,9)$. Wound healing acceleration (10), antibacterial and antifungal properties of scabies have also been reported (11-15). In this study, we evaluated the in vitro activity of methanol extract of $Q$. infectoria (oak galls) against promastigotes and amastigotes of $L$. major.

\section{MATERIAL AND METHODS}

L. major, an Iranian strain of MRHO/IR/75/ER, was acquired from the Department of Parasitology of Razi Institute and cultivated in RPMI 1640 medium with $10 \%$ fetal bovine serum (FBS, complement inactivation conditions: $56^{\circ} \mathrm{C}$ for 30 minutes) at $23 \pm 2{ }^{\circ} \mathrm{C}$. Oak galls were collected from $Q$. infectoria trees in the Baneh region of Kurdistan (Iran) and later approved by a botanist. After being crushed by an electric mill, the galls were grounded and drenched in methanol for extraction. The ground gall was immersed in $80 \%$ methanol $(1: 5 \mathrm{~m} / \mathrm{v})$ and kept in lidded glass jars away from sunlight for 72 hours. The contents of the jars were filtered through sterile gauze and then filter paper (16, 17). The samples were powdered in a vacuum at $40{ }^{\circ} \mathrm{C}$. The extract was refrigerated in opaque glasses until used for testing. $T$ he powder was dissolved in saline, and $0.2 \mu \mathrm{l}$ of the solution was filtered by syringe filters to determine dilution of the extract. Then, $100 \mu \mathrm{L}$ of $L$. major promastigotes in the logarithmic phase of growth (at a volume of $5 \times 10^{6}$ ) were added to the culture medium in the 96-well plates (NEST Scientific, USA). Then, $100 \mu 1$ of each prepared concentration of scabies extract were added to the medium in a 96-well plate, and five wells containing only the medium were considered as controls. The plate was incubated at $23 \pm 2{ }^{\circ} \mathrm{C}$. All tests were repeated four times. The effects of the herbal extract on the parasites were assessed after 24, 48, and 72 hours by direct count method and MTT assay. Fifty mg of MTT powder was placed in a Falcon tube. Then, $10 \mathrm{ml}$ of buffer ( $\mathrm{pH}$ 7.4) was added and the tube was shaken in the dark. A uniform yellow solution was obtained, which was later filtered under a cell culture hood using a 0.2 micron filter into a sterile Falcon tube wrapped completely in tin foil. The tube was stored in the dark until used. Next, $5 \times 10^{6}$ promastigotes of L. major in the logarithmic phase was added to the 96-well plate. The oak gall extract at concentrations of $10,100,500,1000 \mu \mathrm{g} / \mathrm{ml}$ was prepared and $100,500,1000$, and $10000 \mu \mathrm{g} / \mathrm{ml}$ of Glucantime were added to the wells. Each 5$\mathrm{ml}$ ampule of Glucantime ${ }^{\circledR}$ contained $1.5 \mathrm{~g}$ meglumine antimonite equivalent to $0.405 \mathrm{~g}$ of pentavalent antimony (Sanofi-Aventis, France). Furthermore, $100 \mu \mathrm{l}$ of medium containing parasites and $100 \mu \mathrm{l}$ of RPMI with $10 \%$ FBS were added to five wells of the plate as a control. The plate was incubated at $23 \pm 2$ ${ }^{\circ} \mathrm{C}$ for 24,48 and 72 hours. The in vitro survival of promastigotes was assessed by MTT assay. First, $20 \mu \mathrm{l}$ of MTT solution (10\% of total volume, $5 \mathrm{mg} / \mathrm{ml}$ ) was added to each 
well in the dark. After incubating the plate at $23{ }^{\circ} \mathrm{C}$ for 4 hours, $100 \mu \mathrm{l}$ of dimethyl sulfoxide were added to each well. Formazan crystals were dissolved after 15-30 minutes, and a purple color appeared. The optical density of the wells was read at 570 NM using an ELISA reader (BioTek ELx800, USA) (16, 17). Percentage of parasite survival was calculated using the following formula: Cell survival rate $=\left[\mathrm{A}_{\mathrm{T}}-\mathrm{A}_{\mathrm{B}}\right] /\left[\mathrm{A}_{\mathrm{C}}-\mathrm{A}_{\mathrm{B}}\right] \times 100$

$\mathrm{A}_{\mathrm{T}}=\mathrm{Abs}$ orbance of treated cells, $A_{B}=$ Absorbance of blank, $A_{C}=$ Absorbance of control (untreated cells.

Percentage of cytotoxicity was calculated by subtracting the cell survival percentage from 100. We also determined the half-maximal inhibitory concentration (IC50) at which each agent was able to inhibit growth of $50 \%$ of cell population.

Under sterile conditions, all equipment including the anatomy set and medium were transferred under a hood, and several 4-weekold BALB/C mice were euthanized with ether and immersed in $70 \%$ alcohol. The fixed mice were put on expanded polystyrene foam and abdominal skin was notched with scissors. Five ml PBS ( $\mathrm{pH}$ 7.4) were injected under peritoneum of mice. Peritoneum fluid was collected by a syringe in a falcon tube. The solution was centrifuged for 10 minutes at 1500 RPM, the supernatant was discarded, and $5 \mathrm{ml}$ of RPMI containing $10 \%$ FBS and $0.5 \%$ gentamicin were added to the sedimented macrophages. Macrophages were counted with a Neobar slide. Ten parasites were calculated for each macrophage (17). Cell cultures were placed under the hood and round lamelles were put at the bottom of a NEST-12-well plate (NEST Scientific USA). Next, $10^{5}$ macrophages were added to each well and the plates were incubated at $37{ }^{\circ} \mathrm{C}$ and in $5 \% \mathrm{CO}_{2}$ for 24 hours. Then, $10^{6}$ promastigotes of $L$. major at stationary phase were added to the wells. The plates were incubated for 24 hours at $37^{\circ} \mathrm{C}$, extracellular parasites were removed by washing, and fresh medium was added to the plates. Oak gall extract at concentrations of 75, 500, $1000 \mu \mathrm{g} / \mathrm{ml}$ and Glucantime at concentrations of $221,1000,10000 \mu \mathrm{g} / \mathrm{ml}$ were added to each well. Only infected macrophages were put in the two control wells. After 24 and 48 hours, round lamellas were removed, fixed with methanol and then stained with Giemsa. The number of amastigotes inside the macrophages was counted under a microscope using the $100 x$ (oil immersion) objective lens $(16,17)$.

Statistical analysis was conducted in SPSS 16 using one-way analysis of variance. P-values less than 0.5 were considered statistically significant.

\section{RESULTS}

As shown in figure 1, the oak gall extract had potent anti-leishmanial activity against promastigotes in a time- and concentration-dependent manner compared with the control. After 24 hours, the IC50 of the extract was $75.5 \mu \mathrm{g} / \mathrm{ml}$. All concentrations of the extract significantly affected the survival of promastigotes after 24,48 , and 72 hours compared with the control $(\mathrm{P}<0.05)$.

Figure 1- Percentage of survival of $L$. major promastigotes after treatment with different concentrations of the gall extract

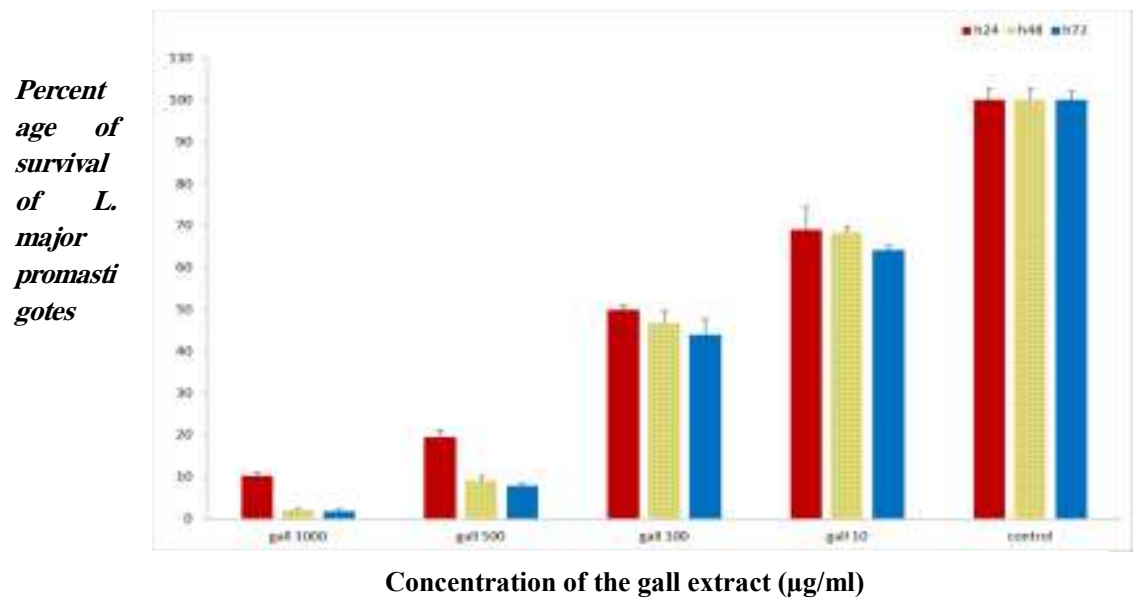


The cytotoxic effect of different concentrations of Glucantime on promastigotes after 24,48 and 72 hours are shown in figure 2 . The IC50 of Glucantime was $221.5 \mu \mathrm{g} / \mathrm{ml}$ after 24 hours. All concentrations of Glucantime significantly affected the survival of promastigotes compared with the control $(\mathrm{P}<0.05)$.

The leishmanicidal activity of the oak gall extract was more significant than that of
Glucantime. Different concentrations of the extract and Glucantime significantly affected the survival rate of amastigotes in microphages compared with the control (Table 1).

The leishmanicidal activity of the oak gall extract was more significant than that of Glucantime. Different concentrations of the extract and Glucantime significantly affected the survival rate of amastigotes in microphages compared with the control (Table 1).

Figure 2- Percentage of survival of $L$. major promastigotes after treatment with different

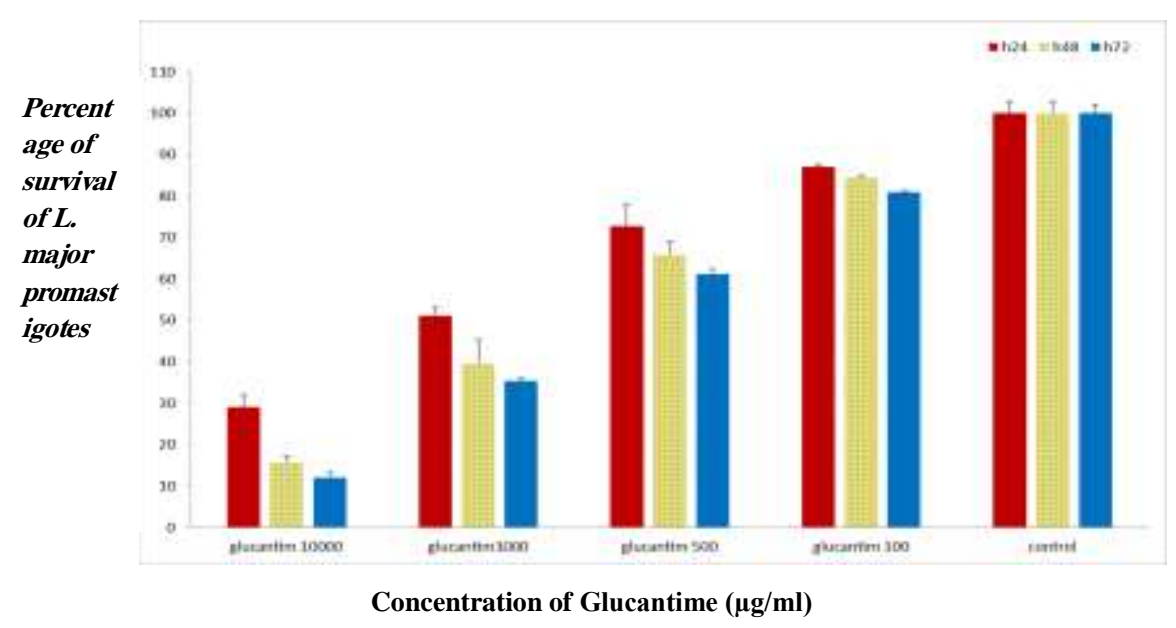

Table1- Average number of amastigotes in macrophages in the control group and under influence of different concentrations of oak gall extract and Glucantime

\begin{tabular}{ccc}
\hline Group & $24 \mathrm{~h}$ & $48 \mathrm{~h}$ \\
\hline Control & $3.52 \pm 021$ & $3.72 \pm 0.09$ \\
Gall $1000 \mu \mathrm{g} / \mathrm{ml}$ & $0.9 \pm 0.11$ & $0.35 \pm 0.07$ \\
& & \\
Gall $500 \mu \mathrm{g} / \mathrm{ml}$ & $1.57 \pm 0.14$ & $1.15 \pm 0.09$ \\
Gall $75 \mu \mathrm{g} / \mathrm{ml}$ & $2.63 \pm 0.08$ & $2.24 \pm 0.06$ \\
Glucantime10000 $\mathrm{gg} / \mathrm{ml}$ & $0.85 \pm 0.14$ & $0.42 \pm 0.05$ \\
& & \\
Glucantime $1000 \mu \mathrm{g} / \mathrm{ml}$ & $1.5 \pm 0.05$ & $1.12 \pm 0.07$ \\
Glucantime $221 \mu \mathrm{g} / \mathrm{ml}$ & $2.71 \pm 0.11$ & $2.53 \pm 0.07$ \\
\hline
\end{tabular}




\section{DISCUSSION}

Leishmaniasis is a complex disease caused by various species of the protozoan Leishmania, an intracellular parasite of humans and animals. It is prevalent in 88 countries and a common problem in tropical and subtropical regions with 1.5 million new cases reported every year $(1,2)$. Pentavalent antimony compounds are considered the firstline drugs in the treatment of cutaneous leishmaniasis. However, the use of these drugs is associated with several disadvantages, including unavailability, high cost and drug resistance (3-5). Therefore, there is a need for herbal and natural alternatives for these compounds with fewer side effects.

In this study, we investigated the antileishmanial effect of methanolic extract of oak galls. Our results revealed that both the extract of oak galls and Glucantime exert antileishmanial effects in a dose- and timedependent manner. However, the effect of the extraction on promastigotes was more notable compared to that of Glucantime, as the IC50 for the extraction and Glucantime was 75 $\mu \mathrm{g} / \mathrm{ml}$ and $221 \mu \mathrm{g} / \mathrm{ml}$ after 24 hours, respectively. After 72 hours, the cytotoxic effect of $1000 \mu \mathrm{g} / \mathrm{ml}$ of the extract and 10000 $\mu \mathrm{g} / \mathrm{ml}$ of Glucantime was $98.2 \%$ and $87.95 \%$, respectively (Figures 1 and 2).

After 48 hours, the mean number of macrophages in amastigotes was 0.35 and 0.42 when treated with $1000 \mu \mathrm{g} / \mathrm{ml}$ of the extract and $10000 \mu \mathrm{g} / \mathrm{ml}$ of Glucantime, respectively (Figure 3). In addition, $1000 \mu \mathrm{g} / \mathrm{ml}$ of the oak gall extract had toxic effects on the macrophages. However, the oak gall extract demonstrated better efficacy against promastigotes and amastigotes of L. major in vitro.

In some studies, the antibacterial, antifungal, anti-inflammatory, antioxidant and antiseptic properties of alcoholic extract of scabies have been demonstrated (11-15). Several studies investigated the effects of plant extracts on promastigotes and amastigotes of Leishmania. Shirani et al. showed the positive effects of ethanolic extracts of thyme, yarrow, and propolis on the healing of wounds caused by L. major (18). In another study, gallic acid and ellagic acid demonstrated great potential as growth inhibitors of promastigote of $L$. major (19).

In study of Sadeghi-Nejad, the IC50 of Allium cepa extract, Ixora brachiate root extract and Glucantime against L. major promastigotes was $0.078,1.25$ and $21.25 \mathrm{mg} / \mathrm{ml}$, respectively (20). In another study, Barati showed that the extract of Shiraz thyme and espand have antileishmanial activity against promastigotes of $L$. major (21). Shemshadi et al. stated that the effect of $0.9 \mathrm{mg} / \mathrm{ml}$ of Caparis root extract on the reduction of lesion size was similar to that of $120 \mathrm{mg} / \mathrm{ml}$ of Glucantime, and both compounds were able to kill $97.8 \%$ of promastigotes after 72 hours (22). In a study by Yosefi et al., $40 \mu \mathrm{g} / \mathrm{ml}$ of Peganum harmala and $200 \mu \mathrm{g} / \mathrm{ml}$ of Alkanna tincturia could inhibit the growth of promastigotes of $L$. major. In addition, the mean number of amastigotes in macrophages treated with $P$. harmala, Alkanna tincturia and control agent was $0.7,0.7$ and 2.3, respectively (23).

In another study, Esmaeili et al. showed that the effective dose 50 of miltefosine and Glucantime against $L$. major amastigotes was $2.20 \mu \mathrm{M}$ and $7.2 \mu \mathrm{M}$ after 72 hours, respectively (24).

In a study by Kheirandish et al., concentrations of 10 and $20 \mathrm{mg} / \mathrm{Kg}$ of oak significantly reduced the mean number of parasites and the mean diameter of lesions in mice (25).

\section{CONCLUSION}

Considering the inhibition of intracellular and extracellular growth of $L$. major, the oak gall extract might be used as an efficient and safe agent for treatment of cutaneous leishmaniasis.

\section{ACKNOWLEDGMENTS}

This article has been derived from the results of a Master's thesis. The authors acknowledge the assistance of the Deputy of Zabol University of Medical Sciences, Iran.

\section{CONFLICT OF INTEREST}

All contributing authors declare that there is no conflict of interest. 


\section{REFERENCES}

1. Kolodzieej H, Kiderlen AF. Anti leishmanial Activity and immune modulatory effects of tannnins and related compounds on Leishmania Parasitised RAW 264.7 Cells. Phytochemistry. 2005; 66(17): 205671.https://doi.org/10.1016/j.phytochem.2005.01.011.

2. Bermarn JD. Human leishmaniasis: clinical, diagnostic and chemotherapeutic developments in the last 10 years. Clin Infect Dis. 1997; 24(4): 684-703. https://doi.org/10.1093/clind/24.4.684.

3. Kobets T, Grekov I, Lipoldova M. Leishmaniasis: prevention, parasite detection, and treatment. Curr Med Chem. 2012; 19(10): 1443-74. https://doi.org/10.2174/092986712799828300.

4. Postigo JA. Leishmaniasis in the World Health Organization Eastern Mediterranean Region. Int $\mathbf{J}$ Antimicrob Agents. 2010; 36(1): 62-65. https://doi.org/10.1016/j.ijantimicag.2010.06.023.

5. Bouvier J, Etges R, Bordier C. Identification of the promastigote surface protease in seven species of Leishmania. Mol Biochem Parasitol 1987; 24:73-79. https://doi.org/10.1016/0166-6851(87)90117-4.

6. Zargaran MR, Safaralizadeh MH, Pourmirza AA, Valizadegan O. Effect of Cardinal Directions on Gall Morphology and Parasitization of the Gall Wasp, Cynips quercus folii. J Insect Sci. 2011; 11: 169.https://doi.org/10.1673/031.011.16901.

7. Sakar MK, Şöhretoğlu D, Ozalp M, Ekizoğlu M, Placente S, Pizza C. Polyphenolic Compounds and Antimicrobial Activity of Quercus aucheri Leaves.Turk.j.chem.2005; 29: 555-9.

8. Kaur G, Hamid H, Ali A, Alam MS, Athar M. AntiInflammatory evaluation of alcoholic extract of galls of Quercus infectoria. J Ethnopharmacol. 2004; 90: 285-92. https://doi.org/10.1016/j.jep.2003.10.009.

9. Kaur G, Athar M, Alam MS. Quercus infectoria galls possess antioxidant activity and abrogate oxidative stress-induced functional alterations in murine macrophages. Elsevier: Chem-Biol Interact. 2008; 171: 272-280. https://doi.org/10.1016/j.cbi.2007.10.002.

10. Umachigi SP, Jayaveera KN, Ashok Kumar CK, Kumar GS, Vrushabendra swamy BM, Kishore Kumar DV. Studies on Wound Healing Properties of Quercus Infectoria. Trop. J Pharm. Res. 2008; 7(1): 913-9. https://doi.org/10.4314/tjpr.v7i1.14677.

11. Basri DF, Fan SH. The potential of aqueous and acetone extracts of galls of Quercus infectoria as antibacterial agents. Indian J Pharmacol. 2004; 37:2629. https://doi.org/10.4103/0253-7613.13851.

12. Nagesh L, Shayam S, Muralikrishna Ks, Kishore G. Antibacterial potential of gall extract Quercus infectoria against entrococcus faecalis an in vitro study. $\mathrm{J}$ Pharmacol. 2012; 30(9): 28-34.

13. Muskhazi M, Nurhafiza y, Nor Azwady AA, Nor Dalilah E. Comparative Study on the In vitro antibacterial efficacy of aqueous and methanolic extracts of Querus infectoria Gall against Cellulosimicrobium cellulanns. Int $\mathrm{j}$ Biol Sci. 2008; 8: 634-8. https://doi.org/10.3923/jbs.2008.634.638.

14. Sharifi A, Gorjipoura A, Sardsiri M, Mohammadi R, Jabarneyad A. Antifungal effect of Quereus infectoria gall on saprolegnia fungi. Armaghan Danesh. 2012; 17(1): 78-84. [Persian]
15. Nur Saedia B, Hasmah A, Wan Nur Amilah WAW. Anti-Candidia activity of Quercus infectoria gall extracts against Candidia Species. j Pharmacy \&Biol Allied Sciences. 2015; 7(1): 15-20.

16. Maroufi y, Ghaffarifar F, Dalimi A, sharifi Z, Hasan Z. Cantharidin-induced apoptosis in Leishmania major Promastigote and macrophages infected by Leishmania major amastigote in vitro.J Mazandaran univ med Sci. 2012; 22(89): 32-40.

17. Chang $\mathrm{K} \mathrm{T}$, Dwyer D. Leishmania donovani. Hamster macrophage interactions in vitro: cell entry, intracellular survival, and multiplication of amastigotes. The Journal of experimental medicine. 1978; 147(2): 515-30. PMID:564391. https://doi.org/10.1084/jem.147.2.515.

18. Shirani-Bidabadi L, Mahmoudi M, Sarabi S, Zolfaghari- Baghbaderani A, Nilforoushzadeh MA, Abdoli H. Moatar The effectiveness of mix extracts of Thyme, yarrow, and propolis on cutaneous Leishmaniasis: a comparative study in an animal model (Balb/c). J Tehran Univ Med Sci. 2009; 66(11): 785-790 [Persian]

19. de Moraes Alves MM, Brito LM, Souza AC, Queiroz BC, de Carvalho TP, Batista JF, et al. Gallic and ellagic acids: two natural immunomodulator compounds solve infection of macrophages by Leishmania major. NaunynSchmiedeberg's archives of pharmacology. 2017; 390(9): 893-903. https://doi.org/10.1007/s00210-017-1387-y.

20. Sadeghi-Nejad B, Saki j, Azish M. Effect of Allium cepa and Ixora brachiata Root Extract on Leishmania major Promastigotes. Jundishapur J Nat Pharm Prod. 2014; 9(2):1-3. https://doi.org/10.17795/jjnpp-15442.

21. Barati M, Sharifi I, Sharififar F. Antileishmanial activity of Artimisia aucheri, Ferula asa foetid and Gossypium hirsutum extracts on Leishmania Major Promastigotes in vitro. JAUMS. 2010: 8(3): 166-172. [Persian]

22. Shemshadi B, Ranjbar-Bahadory Sh, Ahmadi H. Effect of Caparis spinosa root extract on promastigotes and amastigotes of Leishmania major. Jof Paramedical Sci. 2015; 6(1):1823. http://dx.doi.org/10.22037/jps.v6i1.8053.

23. Yosefi R, Ghaffarifar F, Dalimi Asl A. The Effect of Alkanna tincturia and Peganum harmala Extracts on Leishmania major (MRHO/IR/75/ER) in vitro. Iranian $\mathrm{J}$ Parasitol. 2009; 4(1): 40-47.

24. Esmaeili J, Mohebali M, Edrissian GH, Rezayat SM, Ghazi-Khansari M, Charehdar S. Evaluation of Miltefosine against Leishmania major(MRHO/IR/75/ER) in vitro and in vivo Studies. Acta Medica Iranica. 2008; 46(3):191-196.

25. Kheirandish F, Delfan B, Mahmoudvand H, Moradi $\mathrm{N}$, Ezatpour B, Ebrahimzadeh F, Rashidipour M. Antileishmanial, antioxidant, and cytotoxic activities of Quercus infectoria Olivier extract. Biomedicine \& Pharmacotherapy. 2016; 82: 208-15. https://doi.org/10.1016/j.biopha.2016.04.040. 